\title{
EUROPEAN MILESTONES IN THE PROTECTION OF WORKERS' CLAIMS IN THE CASE OF INSOLVENCY
}

\author{
Yury Y. Karaleu \\ School of Business of Belarusian State University \\ e-mail: yykorolev@sbmt.by
}

ORCID: 0000-0002-7178-7563

(C) 2021 Yury Y. Karaleu

This work is licensed under the Creative Commons Attribution-ShareAlike 4.0 International License. To view a copy of this license, visit http://creativecommons.org/licenses/by-sa/4.0/

Quote as: Karaleu, Y. Y. (2021). European milestones in the protection of workers' claims in the case of insolvency. Financial Sciences, 26(1)

DOI: $10.15611 /$ fins.2021.1.02

JEL Classification: K31, G33, J65

\begin{abstract}
The employer's insolvency entails, in addition to the potentially devastating economic consequences of output reduction and the disruption of economic relations, adverse social costs for employees - the loss of jobs and earnings. It is not only the employee and his or her family who suffer a great loss, but the whole community. Thus, society faces the serious question of how to ensure the payment of wages to employees in the case of insolvency and provide a solid framework with which countries can find durable solutions, effectively organise and manage the protection of workers' claims. This paper analyses the achievement in developing European and national systems of protection of workers' claims in cases of insolvency, and shows the progress made by EU countries in arriving at a balance of interests between employers, employees and society in the protection of outstanding claims of employees in the event of their employer's insolvency.
\end{abstract}

Keywords: insolvency, employees' claims, EU directives.

\section{Introduction}

Insolvency has a dramatic impact on employees, and the personal and social costs of business failure have a disproportionately negative effect on them as they and their families may be wholly dependent on a wage as the one and only principal source of sustenance. Employees are considered the most vulnerable of company creditors in the insolvency process because of their lack of ability to diversify their risks, lack of relevant information of the financial position and performance of the company, resources, voice and bargaining power to realize their claims individually. An individual who loses his/her source of income and livelihood will inevitably face difficult living conditions and be compelled to forfeit many rights which, without an income, he/she will not be able to practice and enjoy. 
In addition to losing their jobs following a firm's insolvency, incomplete or unpaid wages to employees by an insolvent company seriously hampers the already critical socio-economic situation facing the unemployed person. It may also have a negative economic multiplier effect, as employees with limited or no purchasing power will not be able to spend locally.

For these reasons policy, legal, and institutional mechanisms become important to address employees wage claims in company insolvency. It is important to ensure that well-functioning mechanisms to address employee wage claims in company insolvency are developed and implemented to address such employee concerns.

\section{Methodology}

Due to the specific features of relevant national laws and the absence of present insolvency proceedings with a universal code of conduct throughout the EU, the study considered three elements that play a vital role in ensuring the balance of interests between employers, employees and society in the protection of outstanding claims of employees in the event of their employer's insolvency:

- legal and institutional technologies of insolvency;

- wage guarantee schemes and social security system;

- corporate social responsibility (CSR) practice (Karaleu, 2020, p. 226).

The first of the above-mentioned tools - legal and institutional technologies of insolvency - concerns all the players in the market and presents the greatest challenge to the EU community. Thus, there is no real justification for poorly defined legal concepts such as the protection of rights to salary and social security to prevail over the damages which may be imposed on employees.

From this point of view, it is important to discuss the following aspects based on the main objectives of this article:

1) to outline the EU progress in insolvency regulations associated with the protection of workers' benefits based on the analysis of the legal framework;

2) to determine the achievements in protecting workers' benefits in cases of insolvency in the EU countries;

3 ) to identify and analyse best practices, challenges, opportunities and initiatives for further implementation.

To address the above objectives, the regulatory and legal similarities and differences between jurisdictions in the field of insolvency regulations, terminology specifics and the challenge of comparative research had to be examined and understood. For example, in different jurisdictions, insolvency proceedings include (Table 1):

This suggests that legal specifics could cause not only differences in the use of formal bankruptcy procedures and enforcement efficiency, even if the bankruptcy laws are broadly similar (Claessens \& Klapper, 2002, p. 10), but also that the certain descriptions or terminologies must be understood in the context in which they are being referred to. 
Table 1. Comparison of Insolvency Proceedings

\begin{tabular}{|l|l|}
\hline \multicolumn{1}{|c|}{$\begin{array}{l}\text { Jurisdiction } \\
\text { Kingdom }\end{array}$} & \begin{tabular}{l}
\multicolumn{1}{c|}{ Insolvency Proceedings } \\
Creditors' voluntary winding-up (with confirmation by the court); \\
Administration, including appointments made by filing prescribed documents with \\
the court; \\
Voluntary arrangements under insolvency legislation; \\
Bankruptcy or sequestration
\end{tabular} \\
\hline Deutschland & $\begin{array}{l}\text { Das Konkursverfahren; } \\
\text { Das gerichtliche Vergleichsverfahren; } \\
\text { Das Gesamtvollstreckungsverfahren; } \\
\text { Das Insolvenzverfahren }\end{array}$ \\
\hline France & $\begin{array}{l}\text { Sauvegarde; } \\
\text { Sauvegarde accélérée; } \\
\text { Sauvegarde financière accélérée; } \\
\text { Redressement judiciaire; } \\
\text { Liquidation judiciaire }\end{array}$ \\
\hline Italia & $\begin{array}{l}\text { Fallimento; } \\
\text { Concordato preventivo; } \\
\text { Liquidazione coatta amministrativa; } \\
\text { Amministrazione straordinaria; } \\
\text { Accordi di ristrutturazione; } \\
\text { Procedure di composizione della crisi da sovraindebitamento del consumatore } \\
\text { accordo o piano); } \\
\text { Liquidazione dei beni }\end{array}$ \\
\hline $\begin{array}{l}\text { Concurso; } \\
\text { Procedimiento de homologación de acuerdos de refinanciación; } \\
\text { Procedimiento de acuerdos extrajudiciales de pago; } \\
\text { Procedimiento de negociación pública para la consecución de acuerdos de } \\
\text { refinanciación colectivos, acuerdos de refinanciación homologados y propuestas } \\
\text { anticipadas de convenio }\end{array}$ \\
$\begin{array}{l}\text { Postępowanie naprawcze; } \\
\text { Upadłość obejmująca likwidację; } \\
\text { Upadłość z możliwością zawarcia układu }\end{array}$ \\
\hline
\end{tabular}

Source: own work.

Literature analysis, analysis of the existing legislation and the mechanism for the application of domestic law corresponding to European directives and international guidelines and standards were used to formulate the conclusions. Comparative studies of local legislation and the relevant European instruments and tools of wage and pension protection were analysed to make more informed and well-argued conclusions and recommendations based upon these studies. More specifically, the inductive method was applied to generalise facts about the national and international approaches to insolvency regulations which have been formulated over the last 
decades. This generalisation helped to identify targeted strategies of cooperation, communication and action for the future development of the protection of employees in the event of their employer's insolvency.

\section{The situation before European initiatives of the protection of employees in the event of their employer's insolvency}

There is a well-established body of EU legislation - in the form of EU directives that deals directly with issues in insolvency situations. Particularly relevant are those directives assuring payment of outstanding claims to employees in the event of their employer's insolvency and potentially contribute to a more positive and stable social climate during the bankruptcy and ensure that it is conducted in a fair way. However, prior to the implementation of the European system of insolvency regulations, the first international legal frameworks for protecting at international level were established by the Protection of Wages Convention No. 95 (Convention No. 95) by the International Labour Organization, ratified by 96 countries (ILO, 1949).

As required by Convention No. 95, wage guarantees should not only be designed to ensure the total payment of the wages due and protect workers from unfair decreases in their remuneration (e.g. as a consequence of the bankruptcy of the company) but also ensure that workers have preferential treatment of service-related claims and privileges in receiving the company's assets upon winding up.

Preferential treatment is when employees (former employees) with wage and other compensation claims are given a statutory priority over other classes of creditors. The highest level of such priority is absolute or so-called super-priority $-\mathrm{a}$ specific mechanism to ensure that employees' claims are first in line (including over secured creditors) to be satisfied on any financial problems of the company (Karaleu, 2018 , p. 18). Nowadays in the majority of jurisdictions, priority creditor status is the primary form of protection conferred upon employees in the case of corporate insolvency.

Later, Convention No. 95 was revised in 1992 by the Protection of Workers' Claims (Employer's Insolvency) Convention No. 173 (Convention No. 173) (ILO, 1992a). This convention with optional provisions for ratifying states (totalling 19) strengthened the privilege system and improved on the standards of Convention No. 95 in three respects as to privileges.

First, article 6 of part II of the convention outlines the minimum scope of the workers' claims covered by privileges. There are four groups of claims: (a) wage claims relating to a prescribed period (not less than for three months prior to the insolvency or termination of employment); (b) holiday pay claims paid as a result of work performed during the year of the insolvency or termination and the preceding year; (c) paid absence claims such as sick leave, maternity leave, etc. relating to a prescribed period (not less than three months); and (d) severance pay. 
Secondly, in accordance with article 7, if the national law sets definite limits for the privileged workers' claims, the prescribed amount must not fall below a socially acceptable level. In order for this right to be ensured, it is required to adjust the amount of claims periodically so as to maintain its value.

Thirdly, according to article 8 , part 1 of the convention, the national law should provide workers with a higher rank of privileges than most other privileged claims, in particular, the state and the social security claims.

Together with strengthening and improving the privilege system, Convention No. 173 in part III defines new means of protection in the form of wage guarantee institutions. Such institutions pursuant to R180 - Protection of Workers' Claims (Employer's Insolvency) Recommendation, 1992 (No. 180) (ILO, 1992b) should have as wide a coverage as possible (art. 7) and could operate based on such principles as (art. 8):

Administrative, financial and legal independence from employers;

Obligatory participation of all employers in the financing of guarantee institutions (unless this is fully covered by the public authorities);

The commitment of obligations, regardless of the fulfilment by others of their obligations in the financing of guarantee institutions;

Collective subsidiary responsibility;

The targeted use of funds for the purpose for which they were collected.

In accordance with article 12 of the Convention No. 173, wage guarantee schemes must cover at a minimum the four groups of claims mentioned above.

\section{European progress of insolvency regulations and protection of employees' claims in case of insolvency}

In EU the first directive after the ILO's initiatives was Council Directive 80/987/EEC of 20 October 1980 on the approximation of the laws of the Member States relating to the protection of employees in the event of their employer's insolvency (The Council of the European Communities, 1980).

Directive 80/987/EEC was applied to employees' claims arising from contracts of employment or employment relationships and those in existence against employers who are in a state of insolvency. For the purposes of Directive 80/987/EEC, an employer was deemed to be in a state of insolvency:

(a) where a request has been made for the opening of proceedings involving the employer's assets (as defined under the laws, regulations and administrative provisions of the Member State), to satisfy collectively the claims of creditors and which make it possible to take into consideration of the above-mentioned claims, and

(b) where the competent authority of the Member State has:

- either decided to open the proceedings,

- or recognised that the employer has been definitively closed down and that the available assets are insufficient to warrant the opening of the proceedings. 
Member States were required to lay down detailed rules for guarantee institutions that should be designed to protect employees' claims. Such institutions had to comply with the following principles, in particular:

(a) the independence of the institutions' assets of the employers' operating capital and the inaccessibility to proceedings for insolvency;

(b) the obligation of employers to contribute to the financing of institutions, unless it is fully covered by the public authorities;

(c) the independence of the institutions' liabilities from the fulfilment of obligations to contribute to financing them.

The guarantee institutions of Member States had to guarantee payment of employees' outstanding claims relating to pay for the period prior to the onset of the employer's insolvency, the date of the notice of dismissal or the date on which the contract of employment was discontinued on account of the employer's insolvency. Member States have the option of limiting the liability of these institutions under specified conditions.

Member States had also taken the measures necessary to ensure that non-payment of compulsory contributions due from the employer, before the onset of his insolvency, to their insurance institutions does not adversely affect employees' benefit entitlements in respect of these insurance institutions in as much as the employees' contributions were deducted at source.

In 2000, the Commission adopted the Communication concerning the Directive on employee protection in the event of employer insolvency (80/987/EEC). The Commission re-examined the directive to decide whether it needed to be amended. One of the difficulties the group of experts identified included cases of transnational insolvency: in the event of transnational insolvency, the group of experts raised the question of how it could be decided which guarantee institution would be responsible for paying the claims. It was agreed that these problems must be addressed at Community level.

Subsequently, significant changes were made to European legislation by Directive 2002/74/EC of the European Parliament and of the Council of 23 September 2002 amending Council Directive 80/987/EEC on the approximation of the laws of the Member States relating to the protection of employees in the event of the insolvency of their employer (The European Parliament and the Council of the European Union, 2002). In particular, in accordance with Art. 4 of Directive 2002/74/EC, Member States shall have the option to limit the liability of the guarantee institutions. If such a limit was established, they shall specify the length of the period for which outstanding claims are to be met by the guarantee institution. This period may not be shorter than a period covering the remuneration of the last three months of the employment relationship prior to or after the date when an employer shall be deemed to be in a state of insolvency (as provided for under the laws, regulations and administrative provisions of a Member State).

Such a minimum period of three months was possible to include in the reference period, with a duration of not less than six months. In cases when the reference 
period was not less than 18 months, Member States may limit the period for which outstanding claims are met by the guarantee institution to eight weeks. In this case, those periods which are most favourable to the employee are used for the calculation of the minimum period.

In any event, when setting the ceilings on the payments made by the guarantee institution, Member States had to ensure the achievement of the social goals defined by Directive 2002/74/EC.

The main provisions of Directive 2002/74/EC were almost completely duplicated by the new Directive 2008/94/EC of the European Parliament and of the Council of 22 October 2008 on the protection of employees in the event of the insolvency of their employer currently in force (European Parliament, 2008). Accordingly, the system of administrative authorities and guarantee institutions was established and launched in accordance with the rules adopted by Member States (European Commission, n.d.).

In practical terms, all those developments have resulted in the creation and implementation of different support instruments for the protection of the employees' claims arising from contracts of employment or employment relationships in European countries. Those instruments and measures ranged from information resources and databases to laws, policies and programmes both local and international. As an example, it should be mentioned here the European Foundation for the Improvement of Living and Working Conditions (Eurofound, n.d.), an instrument that clearly has had an important impact, with intrinsic value as well as a catalytic element for supporting and implementing social and employment policies, promoting social dialogue based on comparative information, research and analysis.

This tripartite European Union Agency, comprising representatives of EU institutions and bodies, Member States and Social Partners (employers and trade unions), was established in 1975 in order to assist the development of better social, employment and work-related policies in Europe and to contribute to the planning and design of better living and working conditions. Eurofound provides research, information and expertise on working conditions and sustainable work, industrial relations, labour market quality change and life and public services to ensure that Europe achieves 'smart, sustainable and inclusive growth' (Eurofound, n.d.).

Through research that examines practical experiences and identifies the drivers of successful change, Eurofound strives not only to document and understand them, but also to disseminate and share good practices for the continuous improvement of the living and working conditions of European citizens. For example, Eurofound's restructuring events database contains factsheets with data on large-scale restructuring events including bankruptcy cases reported in the principal national media in each EU member state (established in 2002).

The database is updated daily and is growing at a rate of approximately 20-30 new entries a week. To date, more than 25,000 restructuring events relating to the $27 \mathrm{EU}$ 


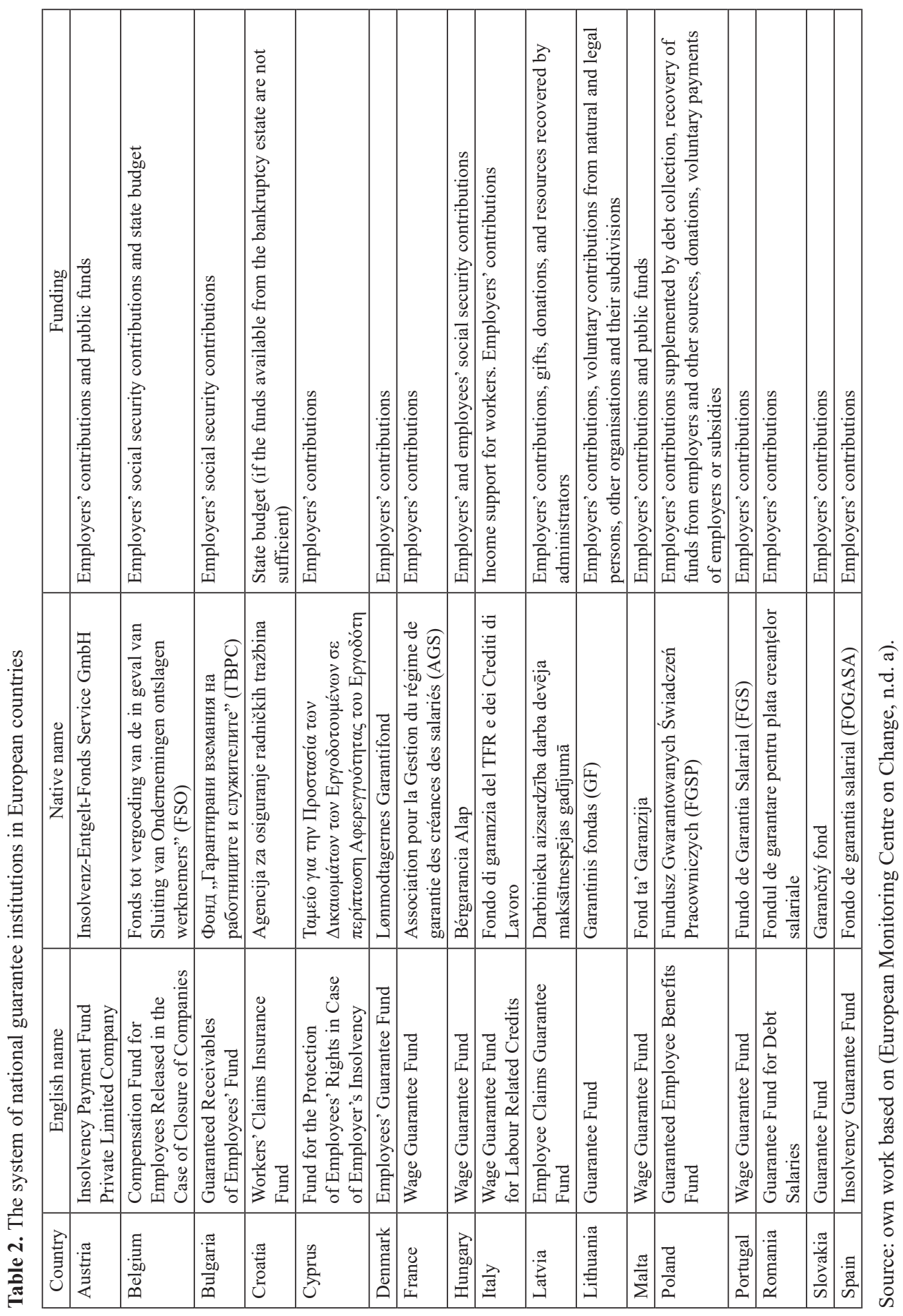


Member States (excluding the UK from January 31, 2020) have been recorded. To be included in the database, an individual case of restructuring must involve the announced loss or creation of at least 100 jobs, or employment effects covering at least $10 \%$ of a workforce of more than 250 people.

The European Restructuring Monitor (ERM) - another instrument of Eurofound on support for restructuring - provides information on more than 300 measures in the Member States of the European Union and Norway promoting support for companies that need to restructure and the affected employees. The aim is to inform national governments, employers' organisations, trade unions and other social partners about what kinds of support can be offered. The support instruments are described in terms of their characteristics, involved actors, funding sources, strengths, weaknesses and outcomes.

Together with information and scientific support, the EU provides access to finance for the companies in cases of restructuring, attracts investors, fosters innovation and mobility, supports start-ups, territorial coordination and internationalisation, shares of labour market information, recognise of informal and non-formal training, social dialogue, etc. However, the real solid base for income support for workers in cases of insolvency was created in the EU through the system of guarantee institutions - basically special funds. Table 2 summarizes the system of special insolvency (wage) guarantee funds or employee claims guarantee funds existing nowadays in the EU.

According to Table 2, in most of Member States of the European Union (in 17 jurisdictions out of 27), including also the United Kingdom, now an ex-member of the union, these services provide recourse for workers who have lost their jobs due to the insolvency of their employer and have not received the full wage or salary owed to them, are presented by guarantee funds. Employees may claim wages, overtime pay, commission, holiday pay, redundancy payment and social security contributions that are owed to them by their employer. Originally created for income support for workers, these funds also provide advice and are used now to strengthen the global response to the serious challenge and threat to international stability and economic development posed by COVID-19.

Member States may apply or introduce measures which are more favourable to employees. They have the option of taking measures necessary to avoid abuses or to refuse or reduce the liability or the guarantee obligation if it appears that the fulfilment of the obligation is unjustifiable because of the existence of special links between the employee and the employer. In some countries, in contrast with insolvency (wage) guarantee funds, they have introduced and implemented special insolvency insurance schemes based on such legislative or other measures as may be necessary to give effect to the rights recognized in the case of insolvency. Such an approach was introduced in particular in Estonia, Finland, the Netherlands, Sweden, etc. In the case of bankruptcy, any outstanding pay and pay for the notice period, as well as any accrued holiday pay, are paid to the employees by the state through the social security 
system, labour ministries and so on. For example, in Greece the scheme is

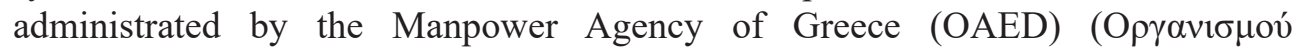

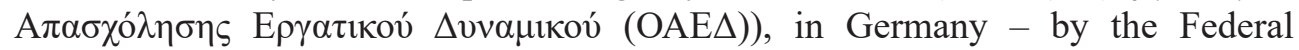
Employment Agency, BA (Bundesagentur für Arbeit), in Ireland - by the Social Insurance Fund (SIF), etc.

Thus, one can see that nowadays EU countries have guarantee schemes which basically rely on the national insolvency (wage) guarantee funds, that will help pay for some employee wage-based benefits upon insolvency, at least for a designated period before the insolvency and up to a predetermined capped amount. This approach correlates with Convention No. 173, mentioned above and all new Member States of the European Union mostly use this tool as a basic guarantee scheme. The case study of Latvia illustrates this approach very well.

\section{Latvia - the case study of employees' protection in cases of insolvency through the Employee Claims Guarantee Fund}

In Latvia, all employees are eligible for the satisfaction of claims due to insolvency of the employer. Insolvency of an employer is in effect from the day when a court judgement regarding the insolvency of the employer enters into legal effect. There is no minimum duration for the contract of employment for workers to qualify.

In cases when the company goes bankrupt, an employee claims guarantee fund has been established in Latvia, operated by the Insolvency Control Service (state agency). The employee can submit the claim to the fund after the court's decision on the company's insolvency (as defined by insolvency law). No claims can be submitted before (European Monitoring Centre on Change, n.d. b). The resources of the fund cover the following payments:

Table 3. The resources of Latvia's Employee Claims Guarantee Fund

\begin{tabular}{|l|l|}
\hline \multicolumn{1}{|c|}{ Type of payments } & \multicolumn{1}{c|}{ Limits } \\
\hline Work remuneration & $\begin{array}{l}\text { the last three months of the employment relationship in the 12 } \\
\text { months before the insolvency of the employer came into effect }\end{array}$ \\
\hline $\begin{array}{l}\text { Reimbursement for annual paid } \\
\text { leave }\end{array}$ & $\begin{array}{l}\text { the right to which has been acquired in the 12 months before } \\
\text { the insolvency of the employer came into effect }\end{array}$ \\
\hline $\begin{array}{l}\text { Reimbursement for other types of } \\
\text { paid leave }\end{array}$ & $\begin{array}{l}\text { the last three months of the employment relationship in the last } \\
12 \text { months before the insolvency of employer came into effect }\end{array}$ \\
\hline $\begin{array}{l}\text { Severance pay connected with the } \\
\text { termination of an employment } \\
\text { relationship }\end{array}$ & $\begin{array}{l}\text { as prescribed by the labour code, the right to which has been } \\
\text { acquired not earlier than in the 12 months before the insolvency } \\
\text { of the employer came into effect }\end{array}$ \\
\hline $\begin{array}{l}\text { Reimbursement for injury } \\
\text { connected with an accident at } \\
\text { work or an occupational disease }\end{array}$ & $\begin{array}{l}\text { for damages for the whole unpaid time period (for the four } \\
\text { subsequent years) }\end{array}$ \\
\hline
\end{tabular}

Source: own work based on (Maksātnespējas kontroles dienests, n.d.). 
The resources of the fund are provided by the state entrepreneurial risk fee (employers' contributions for each employee, the amount determined by the Cabinet of Ministers), by gifts and donations, and by resources recovered by the administrators.

Table 4. Contributions and disbursements from Latvia's Employee Claims Guarantee Fund for 2016-2019, EUR

\begin{tabular}{|l|c|c|c|c|}
\hline \multicolumn{1}{|c|}{ Indicator } & 2016 & 2017 & 2018 & 2019 \\
\hline $\begin{array}{l}\text { Monthly employers' contribution rate for each } \\
\text { employee }\end{array}$ & 0.36 & 0.36 & 0.36 & 0.36 \\
\hline Total contributions & $2,807,069$ & $2,584,005$ & $1,809,562$ & $2,110,504$ \\
\hline Disbursements from the fund & $1,073,519$ & $1,325,238$ & $1,273,756$ & $1,703,074$ \\
\hline The average disbursements per employee & 876 & 930 & 1,017 & 1,342 \\
\hline $\begin{array}{l}\text { Number of employees received payments from } \\
\text { the fund }\end{array}$ & 1,226 & 1,425 & 1,252 & 1,269 \\
\hline
\end{tabular}

Source: own work based on information presented by the Insolvency Control Service of Latvia (Maksātnespējas kontroles dienests, n.d.).

In 2014, in contrast to the current state of affairs, a total of 3,590 employees' claims to the fund were satisfied, in total amounting to 2,663,441 EUR. In recent years, the number of employees who received payments from the fund did not exceed 1,500 claims. At the same time, there was a general increase in the volume of disbursements from the fund. In 2009, due to the economic crisis, the amount of resources in the Employee Claims Guarantee Fund became critically low, and the government limited the payout amount. The maximum payout was linked to the

Table 5. Maximum amount of employees' claims that can be satisfied by Latvia's Employee Claims Guarantee Fund for 2016-2019, EUR

\begin{tabular}{|l|c|c|c|c|c|}
\hline \multicolumn{1}{|c|}{ Type of payments } & $\begin{array}{c}\text { Number } \\
\text { of calendar } \\
\text { days }\end{array}$ & 2016 & 2017 & 2018 & 2019 \\
\hline $\begin{array}{l}\text { Work remuneration and } \\
\text { reimbursement for other types } \\
\text { of paid leave }\end{array}$ & 92 & $\begin{array}{c}92 \times 12,164= \\
1119,09\end{array}$ & $\begin{array}{c}92 \times 12,493= \\
1149,36\end{array}$ & $\begin{array}{c}92 \times 21,205= \\
1950,86\end{array}$ & $\begin{array}{c}92 \times 21,205= \\
1950,86\end{array}$ \\
\hline $\begin{array}{l}\text { Reimbursement for annual paid } \\
\text { leave }\end{array}$ & 28 & $\begin{array}{c}28 \times 12,164= \\
340,59\end{array}$ & $\begin{array}{c}28 \times 12,493= \\
349,80\end{array}$ & $\begin{array}{c}28 \times 21,205= \\
593,74\end{array}$ & $\begin{array}{c}28 \times 21,205= \\
593,74\end{array}$ \\
\hline $\begin{array}{l}\text { Severance pays connected } \\
\text { with the termination of an } \\
\text { employment relationship }\end{array}$ & 30 & $\begin{array}{c}30 \times 12,164= \\
364,92\end{array}$ & $\begin{array}{c}30 \times 12,493= \\
374,79\end{array}$ & $\begin{array}{c}30 \times 21,205= \\
636,15\end{array}$ & $\begin{array}{c}30 \times 21,205= \\
636,15\end{array}$ \\
\hline Total: & & $1,824.60$ & $1,873.95$ & $3,180.75$ & $3,180.75$ \\
\hline Total incl. taxes: & $2,255.02$ & $2,316.01$ & $3,946.99$ & $3,946.99$ \\
\hline
\end{tabular}

Source: own work based on information presented by the Insolvency Control Service of Latvia (Maksātnespējas kontroles dienests, n.d.). 
national minimum wage (NMW) and was limited to 1.5 times the amount of the NMW. In 2018, the size of the Employee Claims Guarantee Fund exceeded 10 million EUR, and the government decided to increase the limit set in 2009, as shown in Table 5.

Table 5 illustrates the great progress of Latvia as a new independent Member State of the European Union on the way of the creation of a solid national system of protection of employees in cases of the employer's insolvency.

\section{The current stage of development of European insolvency regulation}

The new European insolvency regulation - Regulation (EU) 2015/848 was approved by the European Parliament on May 20, 2015 (European Parliament, 2014). The major reason for the revision was to guarantee the sound functioning of the internal EU market and its economic sustainability in times of crises with regard to national insolvency laws.

The main incentive for much of the Regulation (EU) 2015/848 revision quite understandably revolves around the efficiency of application to pre-insolvency and rescue proceedings aimed at giving the debtor a "second chance" or a "fresh start". It improves the efficiency and effectiveness of the insolvency proceedings by strengthening the certainty and clarity of the current jurisdictional framework; harmonisation of insolvency proceedings has cross-border effects opened in respect of the same debtor and strikes a better balance between efficient insolvency administration and protection of local creditors, etc. (Franzina, 2015).

Due to the specific features of relevant national laws of Member States, pursuant to Regulation (EU) 2015/848, recognized as "not practical" to present insolvency proceedings with a universal code of conduct throughout the EU. One of the reasons why workers' benefits remain internationally unregulated stemmed from the fact that different states have different regulations of insolvency and restructuring-related legislation. For example, Eurofound's ERM database on restructuring-related legal regulations provides information on about 461 regulations in the Member States of the European Union and Norway. That figure covers statutory rules and does not take into account local or collective agreements or company-level initiatives. Consequently, the termination of employment contracts, protection of the employees' claims by preferential rights, the status of such preferential rights, etc. should be determined by the law of the Member State in which the insolvency proceedings have been opened (European Parliament, 2015).

However, this should not be an excuse for leaving such an important legal and social issue mainly unregulated, particularly if one takes into consideration the fact that the benefits of insolvency proceedings based on the universal code of conduct are felt much more widely in society and not just by the employees themselves. 
On the other hand, there is no doubt that the issue of the protection of workers' benefits in cases of insolvency so far has not been dealt with sufficiently. Only in article 13 Workers of new Directive on preventive restructuring frameworks, on discharge of debt and disqualifications, and on measures to increase the efficiency of procedures concerning restructuring, insolvency and discharge of debt approved on June 20, 2019 (European Parliament, 2019) the is the scope of individual and collective workers' rights under EU and national labour law stated. Workers' rights under national and EU law should not be affected by the preventive restructuring framework and are presented by the right to collective bargaining and industrial action; the right to information and consultation; other rights guaranteed for example by European Parliament Directive 2008/94/EC, 2008 on the protection of employees in the event of the insolvency of their employer (European Parliament, 2008).

\section{Conclusion}

It is possible to generalise that in the EU considerable efforts have been made to support the protection of workers through the effective implementation of legislative and administrative proceedings, labour laws, different kinds of priorities and preferences, insurance systems and guarantee funds that project employee occupational benefits and wage-related benefits in the case of employer insolvency. Despite the fact that it is "extremely difficult" to develop and implement a universal international (or multinational) model of insolvency that will be acceptable to all Member States (Mevorach, 2007), the international policies of the European Union have borne fruit. The case study of Latvia clearly reflects this: despite some problems and difficulties, Latvia's Employee Claims Guarantee Fund has become a solid foundation of the stable national system of protection of employees in cases of insolvency of the employer.

In addition, as illustrated here, the European policy of paying more attention to the social aspects and consequences of insolvency for workers is combined with the support of debtors' claims and the concept of a 'fresh start'. This reflects the strong international consensus that exists in support of a settlement on the basis of finding a better balance between efficient insolvency administration and the protection of employees' claims in cases of insolvency.

\section{References}

Claessens, S., \& Klapper, L. (2002). Bankruptcy around the world: Explanations of its relative use (World Bank Policy Research Working Paper No. 2865). Washington: The World Bank.

Eurofound. (n.d.). Who we are. Retrieved March 16, 2021 from https://www.eurofound.europa.eu/ about-eurofound/who-we-are

European Commission. (n.d.). Administrative authorities and/or guarantee institutions (Directive 2008/94/EC). Retrieved March 16, 2021 from https://ec.europa.eu/social/BlobServlet?docI$\mathrm{d}=2792$ \&langId $=$ en 
European Monitoring Centre on Change. (n.d. a). Restructuring support instruments. Retrieved March 16, 2021 from https://www.eurofound.europa.eu/observatories/emcc/erm/support-instrument

European Monitoring Centre on Change. (n.d. b). Latvia: Wage guarantee in case of insolvency. Retrieved March 16, 2021 from https:/www.eurofound.europa.eu/observatories/emcc/erm/legislation/ latvia-wage-guarantee-in-case-of-insolvency

European Parliament. (2008). Directive 2008/94/EC of the European Parliament and of the Council of 22 October 2008 on the protection of employees in the event of the insolvency of their employer. Retrieved March 16, 2021 from http://data.europa.eu/eli/dir/2008/94/oj

European Parliament. (2014). Directive 2014/95/EU of the European Parliament and of the Council of 22 October 2014 amending Directive 2013/34/EU as regards disclosure of non-financial and diversity information by certain large undertakings and groups. Retrieved March 16, 2021 from https://eur-lex.europa.eu/legal-content/EN/TXT/?uri=CELEX\%3A32014L0095

European Parliament. (2015). Regulation (EU) 2015/848 of the European Parliament and of the Council of 20 May 2015 on insolvency proceedings. Retrieved March 16, 2021 from https://eur-lex.europa.eu/legal-content/en/TXT/?uri=CELEX\%3A32015R0848

European Parliament. (2019). Directive (EU) 2019/1023 of the European Parliament and of the Council of 20 June 2019 on preventive restructuring frameworks, on discharge of debt and disqualifications, and on measures to increase the efficiency of procedures concerning restructuring, insolvency and discharge of debt, and amending Directive (EU) 2017/1132. Retrieved 16.03.2021 from http://data.europa.eu/eli/dir/2019/1023/oj

Franzina, P. (2015). The new European Insolvency Regulation. Retrieved March 16, 2021 from http:// conflictoflaws.net/2015/the-new-european-insolvency-regulation/

ILO. (1949). Protection of Wages Convention, 1949 (No. 95). Retrieved March 16, 2021 from https:// www.ilo.org/dyn/normlex/en/f?p=NORMLEXPUB:12100:0::NO::P12100_INSTRUMENT_ ID:312240

ILO. (1992a). C173 - Protection of workers' claims (employer's insolvency) Convention, 1992 (No. 173). Retrieved March 16, 2021 from https://www.ilo.org/dyn/normlex/en/f?p= NORMLEXPUB:12100:0::NO::P12100_ILO_CODE:C173

ILO. (1992b). R180 - Protection of workers' claims (employer's insolvency) Recommendation, 1992 (No. 180). Retrieved March 16, 2021 from https://www.ilo.org/dyn/normlex/en/f?p= NORMLEXPUB:12100:0::NO::P12100_INSTRUMENT_ID:312518

Karaleu, Y. (2018). Social responsibility aspects of companies' insolvency. Journal of Corporate Responsibility and Leadership, 2(4), 7-26.

Karaleu, Y. (2020). Interaction between institutional technologies, wage guarantee schemes and corporate social responsibility in respect of the protection of workers' benefits in case of company insolvency. RUDN Journal of Economics, 28(2), 225-238. Retrieved March 16, 2021 from http:// dx.doi.org/10.22363/2313-2329-2020-28-2-225-238

Maksātnespējas kontroles dienests. (n.d.). Darbinieku prasījumi. Retrieved March 16, 2021 from https://www.mkd.gov.lv/lv/darbinieku-prasijumi

Mevorach, I. (2007). Appropriate treatment of corporate groups in insolvency: A universal view. European Business Organization Law Review, 8(2), 179-194. doi: https://doi.org/10.1017/ S1566752907001796

The Council of the European Communities. (1980). Council directive of 20 October 1980 on the approximation of the laws of the Member States relating to the protection of employees in the event of the insolvency of their employer (80/987/EEC). Retrieved March 16, 2021 from https://eur-lex. europa.eu/legal-content/EN/TXT/?uri=celex\%3A31980L0987

The European Parliament and the Council of the European Union. (2002). Directive 2002/74/EC of the European Parliament and of the Council of 23 September 2002 amending Council Directive 80/987/EEC on the approximation of the laws of the Member States relating to the protection of employees in the event of the insolvency of their employer. Retrieved March 16, 2021 from https:// eur-lex.europa.eu/legal-content/EN/TXT/?uri=CELEX\%3A32002L0074 


\section{EUROPEJSKIE KAMIENIE MILOWE W OCHRONIE ROSZCZEŃ PRACOWNIKÓW W PRZYPADKU NIEWYPLACALNOŚCI}

Streszczenie: Niewypłacalność pracodawcy pociąga za sobą, oprócz potencjalnie druzgocących skutków ekonomicznych redukcji produkcji i zakłócenia stosunków gospodarczych, niekorzystne dla pracowników koszty społeczne - utratę pracy i zarobków. Nie tylko pracownik i jego rodzina ponoszą wielką stratę, ale całe społeczeństwo. Społeczeństwo stoi przed poważnym pytaniem: jak zapewnić wypłatę wynagrodzeń pracownikom w przypadku niewypłacalności i zapewnić solidne ramy, dzięki którym kraje będą mogły znaleźć trwałe rozwiązania, skutecznie zorganizować i zarządzać ochroną roszczeń pracowników. W artykule przeanalizowano osiągnięcia w rozwoju europejskich i krajowych systemów ochrony roszczeń pracowników w przypadku niewypłacalności oraz przedstawiono postępy krajów UE w równoważeniu interesów pracodawców, pracowników i społeczeństwa w zakresie ochrony pozostających do spłaty roszczeń pracowników w przypadku niewypłacalności pracodawcy.

Słowa kluczowe: niewypłacalność, roszczenia pracowników, dyrektywy UE. 